\title{
Rotifer diversity in a peat-swamp in southern Thailand (Narathiwas province) with the description of a new species of Keratella Bory de St. Vincent
}

\author{
S. Chittapun ${ }^{1}$ \\ P. Pholpunthin ${ }^{1}$ \\ H. Segers ${ }^{2}$
}

Keywords : rotifers, zoogeography, biodiversity, Keratella, new species, Thailand

We studied the rotifer fauna of one of the most pristine peat-swamps in the Southern Thai province of Narathiwas, To Daeng peat swamp. The samples yielded a total of sixty-seven rotifer species. Of these, three-Keratella mixta (Oparina-Charitonova), Lecane enowi Segers \& Mertens and Monommata dentata Wulfert- are new to the Oriental region and the Thai fauna, one, Keratella taksinensis $\mathrm{n}$. sp., is new to science. The fauna consists mainly of cosmopolitan (sensu lato) species, complemented by some Paleotropical and endemic taxa, and is dominated by littoral-benthonic taxa, especially Lecane and, to a lesser extent, Lepadella.

Diversité des rotifères dans un marais tourbeux du sud de la Thailande (Province de Narathiwas) avec la description d'une espèce nouvelle de Keratella Bory de St. Vincent

Mots-clés : rotifères, zoogéographie, biodiversité, Keratella, espèce nouvelle, Thaïlande.

Une étude des rotifères d'un marais tourbeux vierge dans le sud de la Thaillande, le marais de To Daeng, a révélé un total de 67 espèces, dont trois -Keratella mixta (Oparina-Charitonova), Lecane enowi Segers \& Mertens et Monommata dentata Wulfertsont nouvelles pour la région Orientale et la Thaillande. Une espèce, Keratella taksinensis n. sp., est nouvelle pour la science. La faune est composée en majorité d'espèces cosmopolites (sensu lato), accompagnées par quelques espèces paléotropicales et endémiques. Elle est dominée par des espèces littorales et benthiques, notamment des Lecane et, moins nombreuses, des Lepadella.

\section{Introduction}

Recently, the study of Rotifera inhabiting peat swamps in Thailand, representing the most diverse group of primary freshwater Metazoa in these peculiar tropical ecosystems, has attracted much interest (e.g., Chittapun et al. 1999, Chittapun \& Pholpunthin 2001, Segers \& Chittapun 2001). However, all studies to date, report on peat swamps that have been influenced, to a greater or lesser extent, by human activities such as farming. These and other disturbances have had a substantial impact on the macrophyte vegetation and on water quality, crucial to the zooplankton communities

1. Department of Biology, Faculty of Science, Prince of Songkla University, Hat Yai 90112, Songkla, Thailand.

2. Department of Biology, Ghent University, K.L. Ledeganckstraat 35, B 9000 Gent, Belgium.

Present address : Royal Belgian Institute of Natural Sciences, Freshwater Biology, Vautierstraat 29, B-1000 Brussels, Belgium. inhabiting these environments.

One of the few pristine peat swamps in Thailand is To-Daeng peat swamp in the southern province Narathiwas, and the study of its rotifer fauna may be informative about the natural biodiversity of this habitat type. Such information is required to assess the impact of human activities on tropical peat swamps. Here we report on the rotifer fauna of this peat swamp.

To Daeng peat swamp (101 $55^{\prime} \mathrm{E}-102^{\circ} 03^{\prime} \mathrm{E}$, $06^{\circ} 03^{\prime} \mathrm{N}-06^{\circ} 03^{\prime} \mathrm{E}$, Fig. 1) is the largest pristine peat swamp in Thailand. It covers an area of ca. 17,352 hectares. The region has a tropical monsoon climate, with heavy rainfall from September to January, and a relatively drier period from February to April. The peat swamp developed under the influence of the deposition of marine sediments near the shoreline, and strong, continuous winds that formed a raised sandy beach parallel to the shoreline. This process finally separated a large, elongate depression from the sea. 


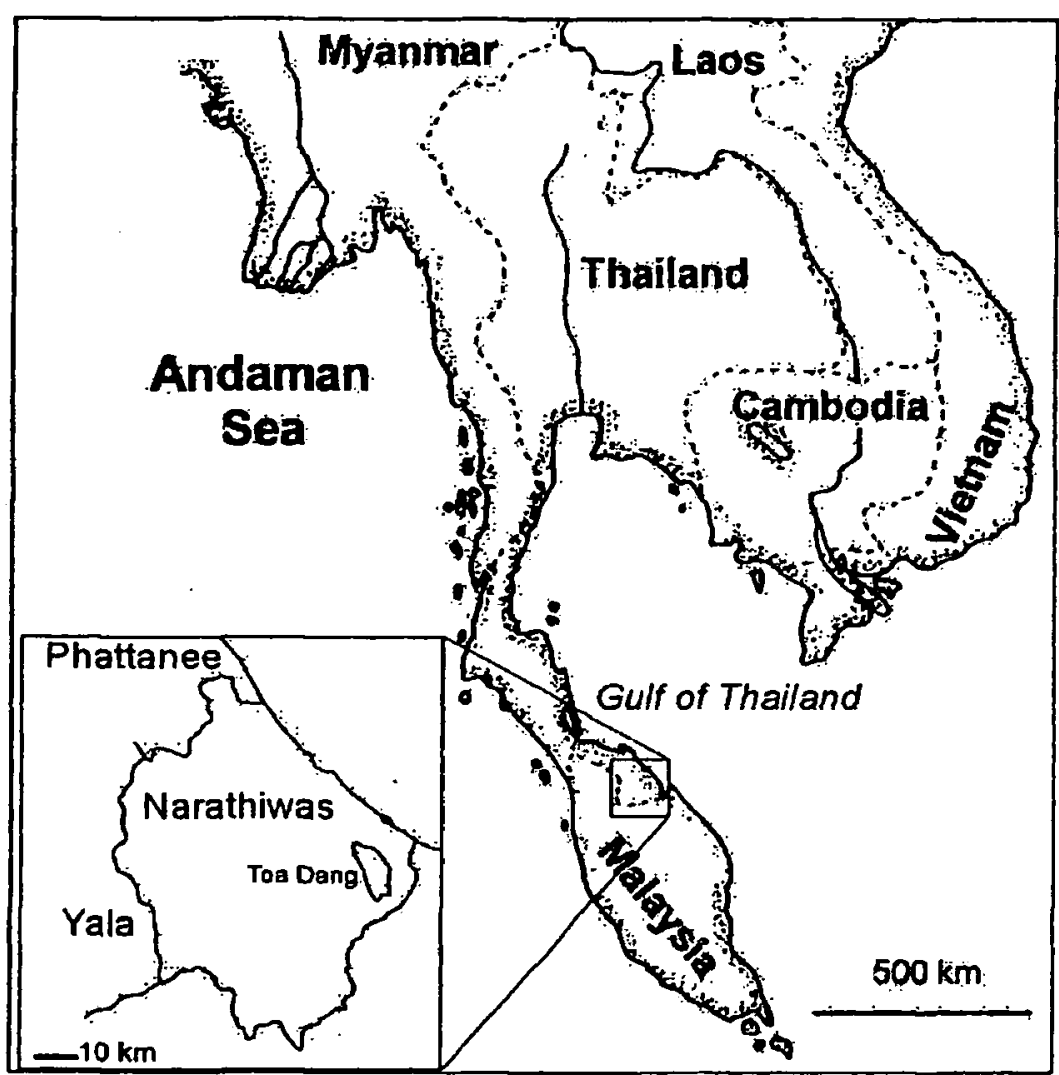

Fig. 1. Map of Thailand showing the location of To Daeng peat swamp in Narathiwas province.

Fig. 1. Carte de la Thaïlande indiquant la localisation du marais tourbeux To Daeng dans la province de Narathiwas.

When the connection to the sea was lost, a freshwater lake and swamp, fed by the heavy precipitation in the area, were formed. However, due to the high Sodium sulphate content of this coastal lake, decomposition rates are relatively low. This resulted in the formation of peat layers of varying thickness by the accumulation of dead organic material. In To Daeng peat swamp, this layer is generally over, or about $50 \mathrm{~cm}$ deep, and reaches a maximum thickness of up to $10 \mathrm{~m}$ in the central area of the swamp. The surface layer of peat (0-30 $\mathrm{cm}$ depth) is pronouncedly acidic ( $\mathrm{pH}$ ca. 4 ), has a dark brown colour, and consists of decomposing organic material. Accordingly, the water in the swamp is acid, and has a characteristic brownish color (Phengklai et al. 1989).

\section{Material and methods}

Qualitative samples were collected in June and October 1998, and February 1999. The samples consist of several horizontal and oblique hauls, using a $26 \mu \mathrm{m}$ mesh plankton net at several stations in the center and near the edges of the swamp. The samples were imme- diately preserved in $4 \%$ formaldehyde solution. Measurements of some physical and chemical parameters were made using a HORIBA, U-10 multimeter (see Table 1). Specimens were sorted, identified, drawn and prepared for scanning electron microscopy (SEM) following Chittapun et al. (1999).

\section{Results and discussion}

\section{Species composition and zoogeography}

A total of 67 rotifer species (66 Monogononta, 1 Bdelloidea) were identified (Table 2). The majority belonged to the genus Lecane ( $40.30 \%$ ), followed by $L e$ padella $(10.45 \%)$. This result corresponds well with existing information on the composition of the rotifer fauna of Thai peat swamps (Chittapun et al. 1999, Chittapun \& Pholpunthin 2001).

One of the species recorded is new to science, and three are new to the Oriental region and Thailand. $\mathrm{Ke}$ ratella taksinensis $\mathrm{n}$. $\mathrm{sp}$. is described below. Keratella mixta (Oparina-Charitonova) (Fig. 2) is a rare rotifer, so far known only from temperate and cold regions in the Northern hemisphere (De Ridder \& Segers 1997). Its occurrence in tropical Asia is surprising and it is, as yet, unclear what factor(s) account for its presence in Toa-Dang peat swamp. Lecane enowi Segers \& Mertens (Fig. 3) has only recently been described from a temporary pond on an old palm plantation in Cameroon (Segers \& Mertens 1997), and the present record is the second of this species. Considering that it is known only from two widely separated geographic localities, it appears premature to speculate on its biogeography. However, it may be part of a group of tropical Old-World taxa, which especially consists of $\mathrm{Le}$ cane species (Segers 1996, 2001). This group is here represented by nine taxa (Table 2), of which only three (Lecane enowi, $L$. simonneae and Scaridium grande) have not yet been recorded from tropical Australia. The third species, Monommata dentata Wulfert, is probably rare only because of the taxonomic difficulty of the genus, making that records of all but the largest and most easily recognized species are few. It is probably cosmopolitan, and has previously been recorded from the Ethiopian, Palaearctic, Nearctic and Australian regions (De Ridder 1986, De Ridder \& Segers 1997). In addition to these, the record of the Thai endemic Lecane superaculeata Sanoamuang \& Segers is noteworthy. This species had already been recorded from several localities in the North and Northeast (Sanoamuang 1997, 1998), and now also from Southern Thailand. 
Table 1. Ranges of some physical and chemical measurements in To Daeng Peat swamp.

Tableau 1. Valeurs de quelques caractéristiques physico-chimiques mesurées dans le marais tourbeux de To Daeng.

\begin{tabular}{lccc}
\hline Date & $18 / 06 / 1998$ & $31 / 10 / 1998$ & $27 / 02 / 1999$ \\
\hline Temperature $\left({ }^{\circ} \mathrm{C}\right)$ & $25.7-35.4$ & $25.7-31.1$ & $25.9-31.4$ \\
pH & $4-6.0$ & $4.0-6.1$ & $4.2-5.9$ \\
Conductivity $\left(\mathrm{mS} . \mathrm{cm}^{-1}\right)$ & $0.04-0.14$ & $0.01-0.42$ & $0.01-0.11$ \\
Turbidity (NTU) & $2.0-40.0$ & $2.0-52.0$ & $3.0-37.0$ \\
\hline
\end{tabular}

Table 2. Rotifers record from To Daeng peat swamp, Narathiwas province, southern Thailand.

Tableau 2. Rotifères dans le marais tourbeux de To Daeng, province de Narathiwas, Sud de la Thaílande.

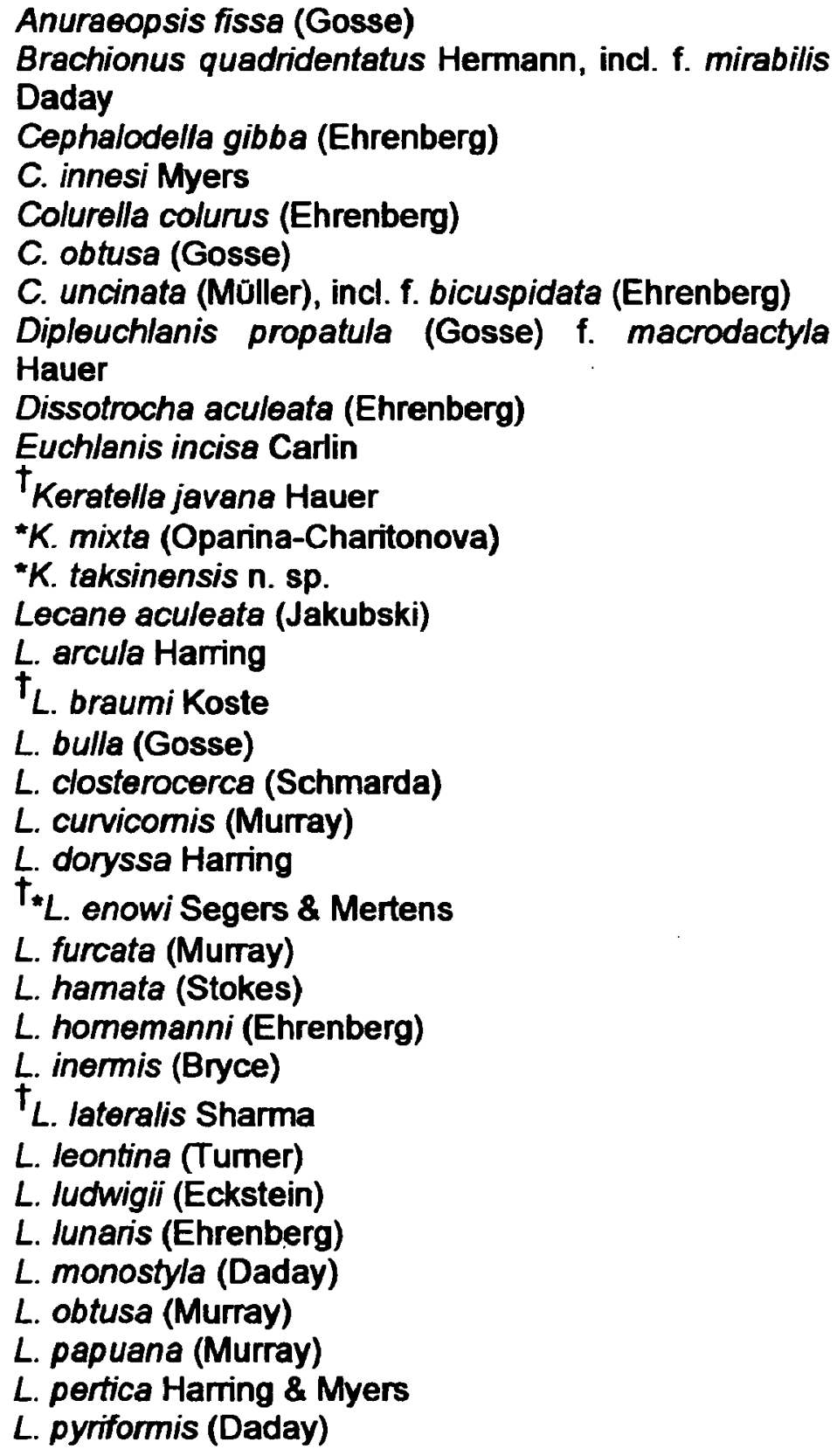

L. signifera (Jennings)

$\dagger_{L}$. simonneae Segers

L. superaculeata Sanoamuang \& Segers

L. tenuiseta Harring

$\dagger_{L \text {. unguitata (Fadeev) }}$

L. ungulata (Gosse)

Lepadella apsicora Myers

$t_{L \text {. discoidea Segers }}$

L. ehrenbergi (Perty)

L. patella (Müller)

L. monodactyla (Bérzins)

L. Thomboides (Gosse)

$t_{L}$. vandenbrandei Gillard

Macrochaetus collinsi (Gosse)

Mantredium eudactylotum (Gosse)

* Monommata dentata Wulfert

M. grandis Tessin

$M$. longiseta (Müller)

Notommata saccigera Ehrenberg

Plationus patulus (Müller)

Platyias quadricomis (Ehrenberg) f. brevispinus

Daday

Polyarthra minor Voigt

${ }^{\dagger}$ Scaridium grande Segers

S. longicaudum (Müller)

Squatinella leydigii (Zacharias) f. longiseta

Pourriot

Testudinella parva (Temetz)

T. patina (Hermann)

T. tridentata Smirnov

Trichocerca brasiliensis (Murray)

$T$. jenningsi Voigt

$T$. siamensis Segers \& Pholpunthin

$T$. similis (Weirzejski) f. grandis Hauer

Trichotria tetractis (Ehrenberg)

* New to the Oriental region and to Thailand

+ Palaeotropical species 

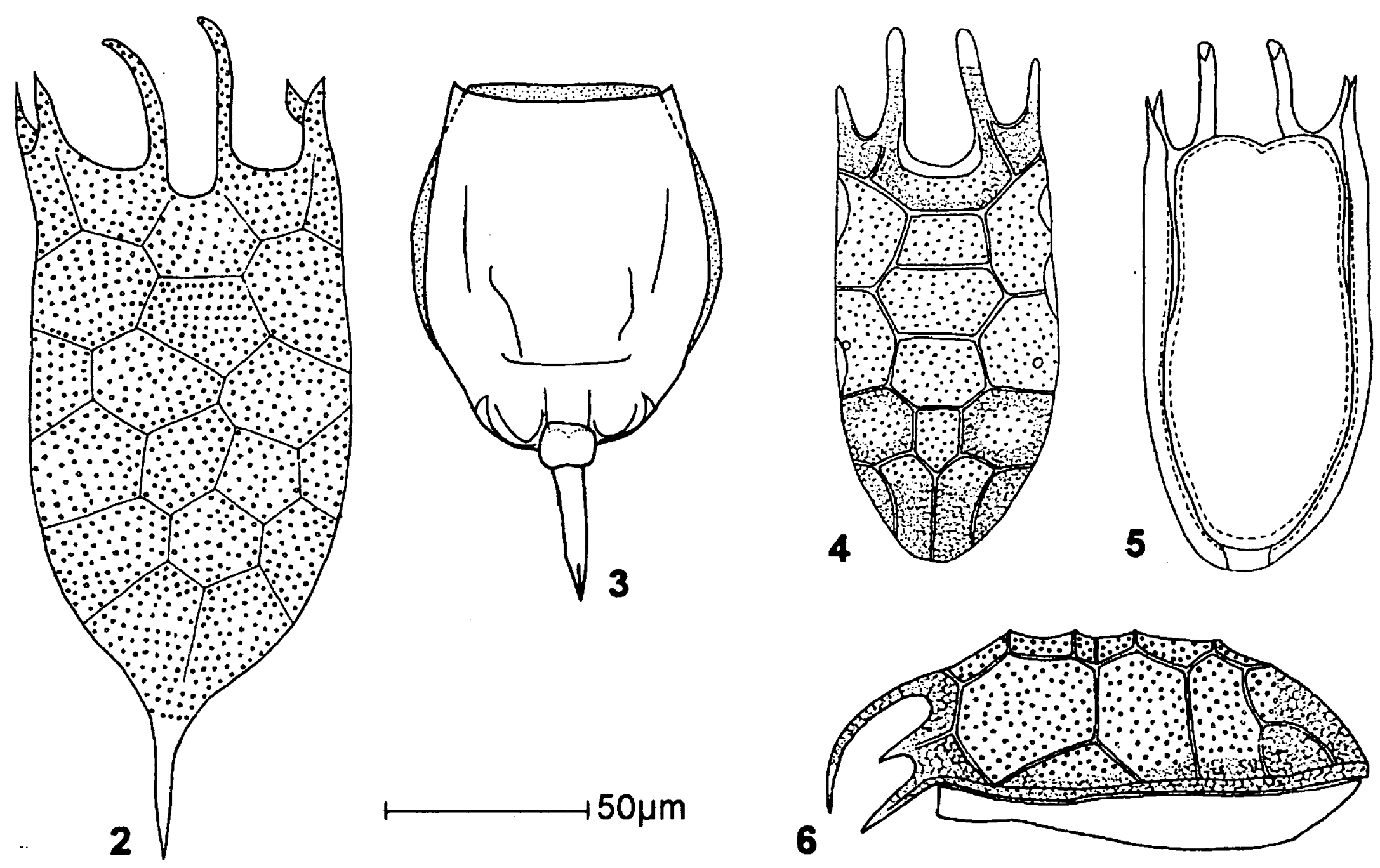

Fig. 2. Keratella mixta (Oparina-Charitonova) - dorsal view ; Fig. 3. Lecane enowi Segers \& Mertens - ventral view ; Figs 4-6. Keratella taksinensis $\mathrm{n}$. sp. - 4: dorsal view, 5: ventral view, 6: lateral view.

Fig. 2. Keratella mixta (Oparina-Charitonova) - vue dorsale; Fig. 3. Lecane enowi Segers \& Mertens - vue ventrale, Figs 4-6. Keratella taksinensis $\mathrm{n}$. sp. - 4: vue dorsale, 5: vue ventrale, 6: vue latérale.

\section{Description of Keratella taksinensis n. sp.}

(Figs 4-6, 7-11)

Type locality : Littoral area of Toa-Dang peatswamp, Narathiwas province, Thailand, coll. October 1998.

Material examined: Holotype and paratype in the royal Belgian Institute for Natural Sciences, Brussels, Belgium (IG: 29717, RIR 136) ; one paratype in the collection of the Institute of Animal Ecology, Ghent University, Ghent, Belgium. Numerous additional specimens present in the original sample (in PSU) from the type locality.

\section{Differential diagnosis}

Keratella taksinensis $\mathrm{n}$. sp. is diagnosed by the presence of four enclosed median facets on the dorsal lorica, posteriorly terminating in a mid-dorsal ridge. As such, it can hardly be confused with any other Keratel$l a$. The new species bears some resemblance with $K$. procurva (Thorpe) and $K$. serrulata (Ehrenberg), but these species have only three or two enclosed median facets, respectively. Four enclosed median facets occur also in $K$. paludosa (Lucks), $K$. ticinensis (Callerio) and $K$. trapezoida Zhuge \& Huang. However, the presence of elongate postero-carinal facets distinguishes $K$. taksinensis n. sp. from these.

\section{Description}

Parthenogenetic female (male unknown) : Lorica stiff, relatively thick, nearly twice as long as wide. Lateral margins nearly parallel, posteriorly rounded. Ventral plate relatively soft, anterially bilobate with median concavity. Dorsal plate stiff; ridges delimiting the facets well-developed. Lorica surface ornamented with large pustules on median and lateral facets, with re- 


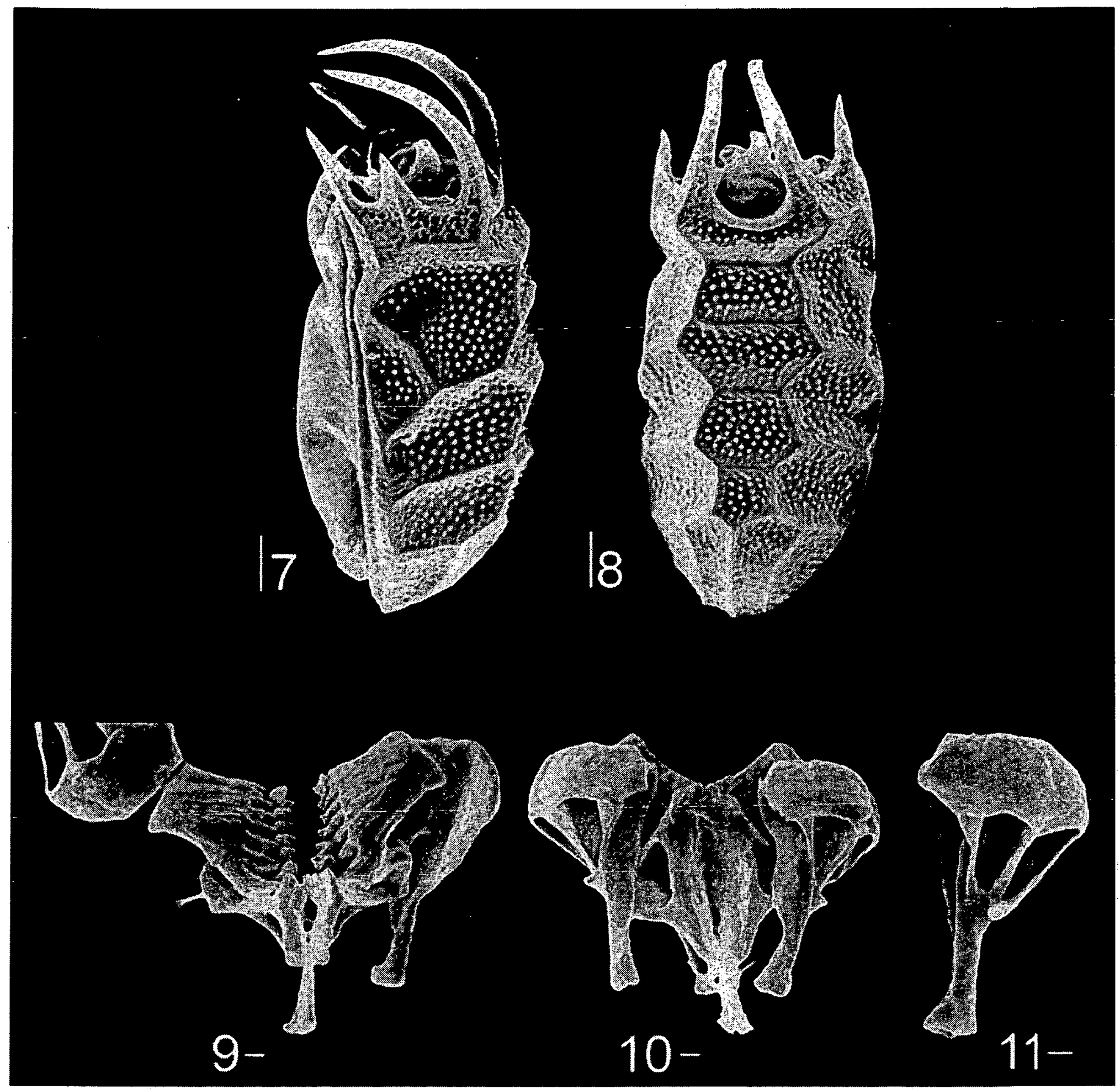

Figs 7-11. Keratella taksinensis n. sp. SEM photographs. - 7: lorica, lateral view, 8: lorica, dorsal view, 9-11: trophi: 9: frontal, 10: caudal view, 11: manubrium, lateral view. Scale bars: 7-8: 10 $\mu \mathrm{m}, 9-11: 1 \mu \mathrm{m}$.

Figs 7-11. Keratella taksinensis sp. n., MEB photographies. - 7: lorica, vue latérale, 8: lorica, vue dorsale, 9-11: trophi: 9: vue frontale, 10: vue caudale, 11: manubrium, vue latérale. Echelle :7 -8: 10 $\mu \mathrm{m}, 9-11: 1 \mu \mathrm{m}$.

ticulate patterns on lateral frontal posterior facets. Six thick, well-developed anterior spines, median pair long and curved ventral, lateral pair longer than intermediate pair, relatively sharp and twice as long as the intermediate pair. Apertures to the lateral antennas approximately half way along the lorica.
Foundation pattern consisting of a row of five median facets. Median frontal area broad, anterior median facet trapezoidal, second hexagonal, wider than long and widest anteriorly, third hexagonal and forth pentagonal, extending posteriorly in a median ridge. A pair of elongate posterocarinal facets present. Three pairs of lateral facets, and a pair of elongate postero-margi- 
nal facets present. A small triangular facet present between the first and second lateral facets. Second lateral facet with aperture to the lateral antenna, this aperture bordered by six fused pustules. No posterior spines.

Trophi malleate, nearly symmetrical. Fulcrum short, with basal plate. Ram triangular, with well developed inner projections consisting of fused, minute teeth. Allulae absent. Both unci with eight teeth, anterior teeth the strongest, with remnants of additional anterior teeth. Two dorsal pairs of teeth weaker than main teeth. Shafts of teeth connected. Manubria with posterior lamellae prolonged along the shaft.

Measurements (in $\mu \mathrm{m}$ ) : Dorsal plate length 87 109 , width $48-61$, Ventral plate length $92-100$, width 41 - 45, Lorica depth 39, Head aperture : antero-median spine length $31-48$, intermediate spine $11-18$, lateral spine 17 - 20. Trophi : fulcrum length 3 , rami width 5 , uncus length 1.4, manubrium length 13 .

\section{Distribution and ecology}

This species is known only from a water body under the hiking trail bridge near To Daeng sanctuary office. Water temperature $25.7-25.9{ }^{\circ} \mathrm{C}, \mathrm{pH} 4.9$ - 5.8, DO $0.89-1.74 \mathrm{mg} . \mathrm{l}^{-1}$, conductivity $0.015-0.028 \mathrm{mS}$. $\mathrm{cm}^{-1}$, turbidity $2-3.6$ NTU.

\section{Etymology}

The name of the new species is a toponym, and is derived from the word 'Taksin', Thai for the Southern part of Thailand.

\section{Acknowledgments}

This work was support by TRF/BIOTEC Special Program for Biodiversity and Training grant BRT 541051 and The Royal Golden Jubilee Ph.D. Program.

\section{References}

Chittapun S., Pholpunthin P. \& Segers H. 1999. - Rotifera from peat-swamps in Phuket Province, Thailand, with the description of a new Colurella BORY DE ST. VINCENT. Internat. Rev. Hydrobiol., 84 : 587-593.

Chittapun S., \& Pholpunthin. P. 2001. - The rotifer fauna of peatswamps in Southern Thailand. Hydrobiologia, 446/447 : 255-259.

De Ridder M., 1986. — Annotated Checklist of non-marine Rotifers (Rotifera) from African Inland Waters. Zoologische Dokumentatie 2. K.M.M.A. Tervuren, Belgium : 123 p.

De Ridder M., \& Segers H., 1997. - Rotifer Monogononta in six zoogeographical regions after publications between 1960-1992. In: Studiedocumenten van het Koninkrijk Belgisch Instituut voor Natuurwetenschappen J. Van Goethem (ed). Brussels, Belgium : $481 \mathrm{p}$.

Phengklai C., Niyomdham C., Premrasmi A., Chirathanakorn K. \& Phuma R., 1989. - Peat swamp forest of Thailand. Thai Forest Bull., 18 : $1-42$.

Sanoamuang L., 1998. - Rotifera of some freshwater habitats in the floodplain of the River Nan, northern Thailand. Hydrobiologia, 387/388: 27-33.

Sanoamuang L. \& Segers H. 1997. - Additions to the Lecane fauna (Rotifera: Monogononta) of Thailand. Internat. Rev. Hydrobiol., 82 : 525-530.

Segers H., 1996. - The biogeography of littoral Lecane Rotifera. Hydrobiologia, 323 : 169-197.

Segers H. 2001. - Zoogeography of the Southeast Asian Rotifera. Hydrobiologia, 446/447 : 233-246.

Segers H. \& Chittapun S. 2001. - The Interstitial Rotifera of a Tropical Freshwater Peat Swamp on Phuket Island, Thailand. Belg. J. Zool., 131 (Suppl. 2) : 65-71

Segers H. \& Mertens J. 1997. - New Rotifera from the Korup National Park, Cameroon. J. Nat. Hist., 31 : 663-668. 